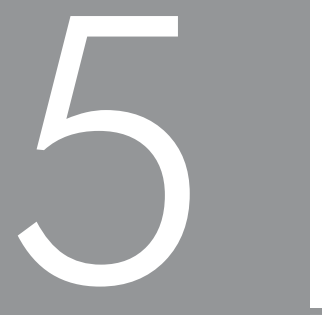

\title{
UTILITARIANISM AND THE FATE OF HUMANITIES IN SOUTH AFRICAN HIGHER EDUCATION
}

\section{THE WITS EXPERIENCE}

\section{Fatima Adam \& Michael Cross}

\section{INTRODUCTION}

The humanities are plagued with concerns about their survival in the context of an increasingly market-driven society in which education has become a commodity that is valued more for its links to economic and political utility and less for its links to citizenship, cultivation of the mind and other intrinsically driven imperatives. While all higher education fields are faced with this dilemma, the humanities are most affected because of their traditional emphasis on highly intrinsic educational outcomes. A case study was undertaken to explore the implications of this new socio-political and economic environment for curriculum transformation at the Faculty of Humanities at the University of the Witwatersrand (Wits). In this chapter we argue that there is a shift toward utilitarian curriculum discourses in the Faculty. However this shift occurs in complex ways and is not easily predictable.

In current debates utilitarianism demarcates the epistemological and pedagogical boundaries between two distinct curriculum discourses playing out in the humanities. The first is bound up with the tradition of liberal arts education associated with the 'ivory tower' conception of the university as an institution above the social order and Eurocentric conceptions of knowledge characterised by principles and values such as the enculturation of the mind (Sanderson 1993), disinterested pursuit of knowledge or knowledge as an end in itself (Muller 2000), discipline-based knowledge (Sanderson 1993), citizenship education (Enslin 2003), and critical thinking and personal autonomy (Tsui 2002). In an attempt to explain this perspective, philosopher Michael Oakeshott ${ }^{16}$ (2004, cited in Fish 2009) suggests that "there is an important difference between learning which is concerned with the degree of understanding necessary to practice a skill, and learning which is expressly focused upon an enterprise of understanding and explaining". Taking this further, Fish (2009) proposes on his blog that this encompasses

16 Oakshott M. 2004. The character of a university education. In: L O'Sullivan (ed). 2004. What is history and other essays. Imprint Academic. 383. 
"understanding and explaining anything as long as the exercise is not performed with the purpose of intervening in the social and political crises of the moment, as long, that is, as the activity is not regarded as essentially instrumental - valued for its contribution to something more important than itself" (Fish 2009). This perspective has been increasingly under attack for its perceived in-utility and irrelevance in the face of the challenges facing contemporary societies.

The second is the emerging trend which calls for a more engaged conception of higher education and judges its value with reference to their relevance and direct links to the social and economic world. In this perspective, higher education is compelled to abandon its ivory tower, insular, distant and abstract characteristics for one that is more responsive to and closely aligned with the needs of society. Driven by both economic and political imperatives, this increased focus on responsiveness has led in many instances to a shift from mode 1 to mode 2 knowledge approaches (Gibbons, Limoges, Nowotny, Schwartzman, Scott \& Trow 1994), from academic/theoretical to 'professional' programmes that prioritise curricula with a focus on skills, application and problem solving, with profound implications for the arts and the humanities.

These perspectives have fuelled debates about the survival of the humanities in higher education settings. For some the new generation of universities must become more intricately linked to industry and society needs, producing the requisite skills and competencies to contribute to the economy (Dovlo 2007). However, for others this ethic of productivity and efficiency - the ultimate expression of utilitarianism - destroys some of the key elements of what it means to be educated in a socially complex and ever-changing society. Opponents of the narrowly constructed instrumentalist perspective believe that educational goals must be broader than merely to fulfil the immediate needs of society. Thus the focus must also be on knowledge development as an end in itself and on broader societal goals such as critical thinking and reasoning. Many opponents of the economically driven utility discourse believe that fields deemed impractical in social and economic terms run the risk of being deemed unnecessary; and academic specialists in these fields may "come to be seen by everyone (not just those outside the academy) as unaffordable anomalies" (Donoghue 2008:69). This, it is argued, will lead to the decline of the humanities as a knowledge form and severe battles for its survival. Titles such as Bonfire of the Humanities (Hanson, Heath \& Thornton 2001), The Demise of the Humanities Department (Tapp 1997), and Crisis in the Humanities (Perloff 2001) are testimony to the deep concern for the survival of the humanities. However, it must be noted that there are those who consider the 'crisis of the humanities' as an unwarranted overstatement. ${ }^{17}$

In this chapter we explore whether the Oakeshottian ideal can still flourish in the humanities in today's South African academic context. If not, what possibilities or opportunities are available for the future of the humanities? We address this question

17 In fact, John Searle (1990:1) said, "I can recall no time when American education was not in crisis." 
with reference to the experience of the Faculty of Humanities at Wits. In doing so, we argue that while Donoghue's claim about the shift toward utilitarian practices in the humanities is gaining momentum in South African higher education, this shift occurs in varied ways, resulting in a number of different curriculum outcomes. It challenges the claim about the decline of the humanities. It suggests that, rather than a decline, the Wits experience can better be described as that of recomposition of the field of the humanities as expressed in the combination of disciplinary and interdisciplinary approaches, integration of mode 1 and mode 2 of knowledge (theory and application concerns) and increasing professionalisation of certain domains of knowledge. It shows that curriculum reform is the result of a complex interplay of a number of external (markets, student needs, efficiency) and internal (disciplinary identity, structure of discipline) factors whose outcomes are not easily predictable. However we do raise concerns about the fact that some programmes will be lost in the process and also that in extreme cases the utilitarian agenda can undermine some of the principles and practices that are renowned in the humanities, and in so doing destroy the essence of the humanities.

\section{MARKETS, SOCIETY AND DISCIPLINARY 'GRAMMAR' IN CURRICULUM CHANGE}

Generally, the literature indicates that there are significant curriculum reform processes underway in higher education, as a result of new trends in the world economy and recent socio-economic and political pressures. While higher education has always undergone changes as societies change, the sector seems to be experiencing more significant and fundamental changes than previously. The key claim emanating from the literature proposes that the new socio-political and economic context requires higher education to become responsive and relevant to the needs of society (Beck \& Young 2005; Castells 2001; Gibbons 2000; Kraak 1997). This is the result of the increased dependence of the economy on knowledge, and the increased pressure for higher education to support the needs of the global economy by producing the 'high skills and high knowledge' required to serve the economy in the 21 st century and the calls to improve efficiency and productivity in higher education. This pressure to strengthen relationships between higher education and workplace needs and higher education and society raises two contesting views about the goals and purpose of higher education which is underpinned by the notion of utility.

Utilitarianism here has been adapted from sociological theories that refer to its relationship with economic or pragmatic viewpoints linking the whole of social action to instrumental rationality (Duncan 2008). In curriculum circles it refers to an instrumentalist view of education that focuses on the use of education in the society rather than being an end in itself. Duncan (2008:26) points out that in this approach

[p]olitical, economic and commercial strategy takes over as the very raison d'être of the university; and the languid atmosphere of impartial scholarship and scientific curiosity is infected by the competitive quest for money and power ... For those in higher education, this political development is a double-edged 
sword. On one hand, it allows us to promote the benefits of education and research in 'hard' economic, as well as social and cultural, terms. This gives greater political weight to arguments for enhancing student participation rates, investing in research, and maximizing the commitment of public finances to tertiary education. On the other hand, such a utilitarian economic discourse on the value of knowledge and higher education will undermine the traditional ideal of a disinterested and impartial pursuit of 'truth', and hence pose a threat to academic freedom.

This shift toward utilitarian discourses in higher education reflects the increasing influence of externally driven factors in the sector. Factors driving curriculum can be divided into two main categories: (1) intrinsic or internal factors directly related to the content knowledge and its epistemological basis; and (2) extrinsic factors or those arising out of external pressures, as well as global, national and institutional factors, or those related to the academic actors involved. Thus while higher education has always been influenced by both extrinsic, as well as intrinsic factors, extrinsic factors have become increasingly dominant in driving curriculum change.

Extrinsic factors have become much more influential in driving curriculum reform processes and outcomes than in previous centuries. Thus the academic community and the discipline are no longer the key determinants of curriculum in higher education. Today, external drivers such as political and economic factors seem to play an equally important role in determining the outcomes of higher education offerings. While this pressure exists across faculties, Humanities is particularly affected because its curriculum has generally been underpinned by traditional liberal education which focused heavily on the inner. Thus the faculty has been associated with education that is aimed at cultivating cultural, social and political understandings and not at serving extrinsic needs (McCabe 2000).

Underpinning debates on extrinsically versus intrinsically driven curriculum reform is the idea of utility embedded in utilitarian discourses, i.e. discourses that advocate direct benefits of higher education to the individual and society beyond the cultivation of the mind based on humanist enquiry for its own sake. As an instrumentalist discourse, utilitarianism vacillates from narrow emphasis on economic benefits focused on utilitybased knowledge related to the world of work and pragmatic skills-based approaches (Kraak 2000:14) to the emphasis on wider societal benefits in terms of inculcation and promotion of social values such as human rights, social justice, equality and equity.

It must be noted that while the literature offers relatively clean demarcations between extrinsic and intrinsic factors, Frank and Gabler (2006) offer a more complex and messier framework with regard to this debate. They argue that while external drivers such as markets and policy have come to play a critical role in curriculum change, these changes are also driven by intrinsic factors related to the changing conceptions of what constitutes valid knowledge in society (e.g. the conception of cosmology and ontology) (Frank \& Gabler 2006:20). In this regard, they show for example that when the arguments on creationism were superseded by the theory of evolution as an 
explanation of existence, the curriculum changed accordingly. Furthermore, the rise of egalitarianism and its prominence over traditional authoritarian structures in society affected the nature of knowledge in the humanities. For example, knowledge shifted from a focus on 'gods and masters' to a focus on knowledge of ordinary people and democratic practices. Frank and Gabler (2006) suggest that in History, for example, this meant that a curriculum with a focus on kings and a few powerful men no longer had currency. Instead a curriculum that recognises the capacity and power of ordinary citizens to act took precedence (Frank \& Gabler 2006:20). This shift to ordinary citizens with the capacity to act and influence their lives has increased the power of education that is able to explain and influence everyday life, i.e. the utilitarian discourse gained status and momentum in defining what constitutes knowledge.

In terms of curriculum, the differences reside on the emphases of the knowledge approach as illustrated in Table 5.1 below.

TABLE 5.1 Characteristics of the knowledge discourse

\begin{tabular}{|l|l|}
\hline Traditional approaches to knowledge & Utilitarian approaches to knowledge \\
\hline Disciplinary & Inter-and multi-disciplinary \\
\hline Pure & Applied \\
\hline Conceptual and theoretical & Contextual \\
\hline Critical thinking & Problem solving \\
\hline Theory & Skills and competence \\
\hline General & Specific \\
\hline Not necessarily linked to work & Directly linked to work \\
\hline
\end{tabular}

Thus, universities that once prided themselves on discipline-based knowledge underpinned by an emphasis on academic, theoretical and conceptual enculturation, and privileged particular modes of analysis and modes of argumentation based on a mastery of discipline-rooted concepts, are turning to skills development and workplace readiness (Ensor 2002:274; Gibbons et al 1994; Scott 1997). These emerging approaches represent a challenge to the long-standing practices associated with programmes in the arts and humanities. Opponents of these approaches point to the danger that the new emphases pose to the purposes of the humanities or liberal arts education (Readings 1996).

We must stress, however, that the comparison in the table is just a heuristic model through which to make sense of what appears to be a more complex and messy institutional curriculum scenario at Wits. The dichotomies are not always reflective of the complexity; they appear revealing in so far as they highlight emerging trends. Different schools and different disciplines experience curriculum pressures in different ways depending on their institutional context, disciplinary strengths or the sense of identity associated with their field, which give rise to different curriculum discourses and practices (Muller 2003). One must caution against explaining these changes through totalising discourses that overlook historical specificity and contextual complexities. 


\section{CURRICULUM DISCOURSES AND TRENDS AT THE UNIVERSITY OF THE WITWATERSRAND}

This chapter was drawn from the data of a case study of the Faculty of Humanities conducted as part of a PhD at Wits University (Adam 2009). Since the Faculty represented a large entity, decisions had to be made about what 'slice' of the entity would be selected for detailed investigation. An attempt was made to combine both breadth and depth of data collection strategies.

This study sought to explore curriculum reform practices and trends in the Faculty of Humanities at the University of the Witwatersrand in the context of the drive toward utilitarian curriculum practices. The Faculty of Humanities comprises five schools (Arts, Education, Social Sciences, Community and Human Development and Language and Literature). The study comprised an analysis of relevant documents, as well as interviews with staff members in the different schools and departments and it combined a breadth and depth approach by focusing broadly on all five schools and more specifically and in greater detail on the School of Social Sciences and the School of Education.

\section{CONTINUUM OF DISCOURSES: FROM TRADITIONAL TO UTILITARIAN}

The ultimate question is: Has the Faculty of Humanities at the University of the Witwatersrand remained the same as it has been since its inception or has it transformed radically into something else? The Faculty of Humanities at the University of the Witwatersrand can no longer be defined by the traditional liberal arts discourse that characterised it since its inception. It now has a range of curriculum responses and outcomes that can be located on a continuum from the traditional liberal discourse to the utilitarian discourse. The nature and extent of these shifts vary across schools and programmes and their relationship to the old traditional form also varies. Thus while it cannot be defined by its traditional liberal form, it also cannot only be defined by utilitarian approaches. Analysis of the data suggests that the faculty is a complex mix of ideas and identity that spans from the traditional liberal discourse to the utilitarian discourse. Even within these discourses there are variations of outcome.

Historically, the humanities has been a privileged disciplinary field in Englishmedium universities, particularly at the University of the Witwatersrand, while in Afrikaans-medium and historically black universities, main centres of diffusion of the conservative Afrikaner Christian Nationalist ideology, humanities became academic disciplines designed to pursue apartheid ideological indoctrination. In English-medium universities, radical scholarship in its neo-Marxist and Africanist strands (e.g. the Black Consciousness movement), found a home in the humanities which managed to focus on the anti-apartheid project while also celebrating the ideals of liberal arts education.

Recently, however, the university has explicitly embraced utilitarianism. The institution's mission statement 'Shaping the Future'18 calls for a balance between academic and

18 Framework for academic restructuring, 2000, University of Witwatersrand, S2000/125: 1. 
professional concerns which foregrounds the link between education and the labour market. This has triggered a multiplicity of responses at curriculum level: "There's huge heterogeneity across the faculty. ${ }^{\prime 19}$ Variations are considerable across schools, departments or individuals, as shown by the responses quoted below:

I think that the curriculum reform pressure is very uneven in different disciplines.

... there were major reform periods locally in certain disciplines ... that in other disciplines were not felt to the same extent ... ${ }^{20}$

Again, you can't look at the school as a unitary grouping. ${ }^{21}$

These curriculum-related responses can be located within a continuum from a traditional humanities curriculum with emphasis on liberal arts education to a heavily utilitarian curriculum, driven by utility and market responsiveness concerns. Thus there are programmes that operate within a strict disciplinary knowledge basis and have generally maintained their 'old' traditional approach. These are concerned with the idea of higher education as the enculturation of the mind, which widens opportunities for self-development, self-enrichment and self-fulfilment in society and the preparation of the individual for the world of work within the framework of the traditional liberal arts education (e.g. philosophy, anthropology). There are programmes that attempt to combine utility approaches with the traditional academic approach in a somewhat hybrid mode (see Figure 5.1). This has led to an increasing professionalisation of the humanities curriculum with the introduction of four-year BA professional programmes in fields such as Law, as well as market-oriented courses such as ICT in Humanities, History and Tourism, Heritage Studies and so forth. There are also programmes that are increasingly driven by narrow market (income-generation) or interventionist concerns particularly in professional education schools.

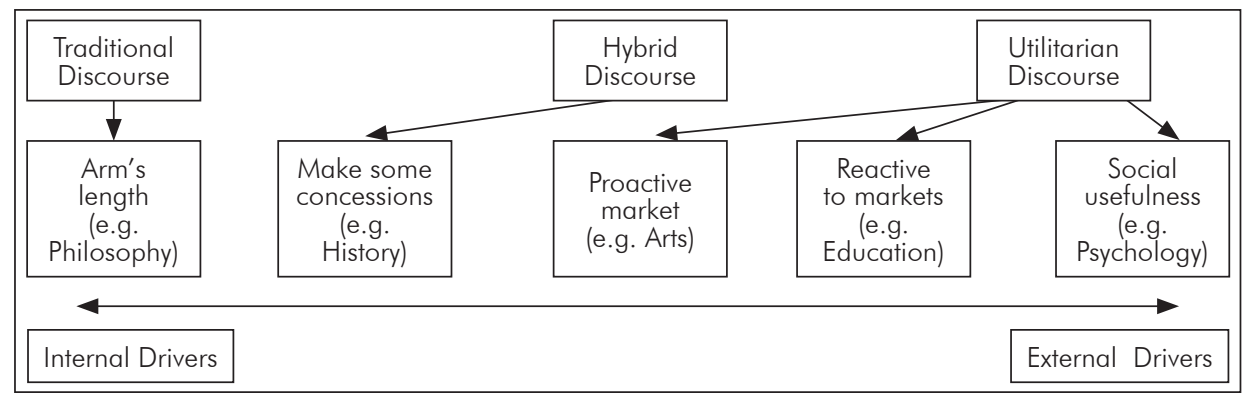

FIGURE 5.1 Continuum of discourses in the faculty

19 Interview, School of Social Sciences, 7 February 2007.

20 Interview, Faculty management, 29 March 2006.

21 Interview, Faculty management, 15 February 2006. 
One of the key manifestations of this reform process is the implication it has for the ways in which the disciplines are reconstituting themselves. While at the undergraduate level the discipline remains the key organising unit of knowledge in the faculty, ${ }^{22}$ disciplines are transforming in various ways to meet new socio-economic and political needs. This has resulted in a number of changes in the faculty, including the expansion of programmes in some disciplines, the closure of programmes in other disciplines, the development of new curriculum in more applied and skills-based disciplines, and the emergence of new interdisciplinary programmes.

Financially viable disciplines or those with strong identities are generally in a stronger position to be proactive about where they would like to position themselves on this continuum, while disciplines that are faced with financial difficulties and have weak identities tend to be reactive to the context and stand a chance of making more compromises along the way. Generally the changes informed by these discourses range from departmental closures, abeyance or discontinuation of courses, modularisation or repackaging and proliferation of courses, interdisciplinarity and thematic reconceptualisation of curriculum, regionalisation and recontextualisation of disciplinary knowledge. We look at these trends in more detail in the following sections, starting with a schematic representation in Table 5.2.

TABLE 5.2 Summary of trends across the faculty

\begin{tabular}{|l|l|}
\hline Summary of trends & Examples \\
\hline $\begin{array}{l}\text { Programme, discipline and course } \\
\text { closures }\end{array}$ & $\begin{array}{l}\text { - Religious Studies Department } \\
\text { - History course on British Politics and Government } \\
1760-1784 \\
\text { - History of Education course }\end{array}$ \\
\hline $\begin{array}{l}\text { Modularisation, repackaging and } \\
\text { course proliferation }\end{array}$ & $\begin{array}{l}\text { - Sociology offered } 11 \text { additional modules between } \\
1999 \text { and } 2005\end{array}$ \\
\hline $\begin{array}{l}\text { Regionalisation, inter-disciplinarity } \\
\text { and thematic approaches }\end{array}$ & $\begin{array}{l}\text { - Heritage Studies } \\
\text { - Forced Migration }\end{array}$ \\
- Journalism, Media Studies \\
- Policy and Management Studies in Education \\
- Film and Documentary History \\
- Democratic Citizenship and Human Rights Education
\end{tabular}

22 For example, Psychology is very popular with students. 
Summary of trends

Commodification (professionalisation or vocationalisation of humanities curriculum)

\section{Examples}

Promotion of short courses strategy for income generation:

- Business English

- Professional development (local government, finance and budgeting, etc.)

- Market-driven modules

- Sociology of Health and Illness

- IT in Humanities

\section{UNVIABLE PROGRAMMES, DISCIPLINES AND COURSES CLOSE DOWN}

Between 1995 and 2005 Wits terminated and rationalised a number of modules, programmes and departments. In some instances, these changes were a result of market-driven, proactive shifts in strategy-applied conceptions of knowledge (mode 2), while in other instances they were reactive responses to low student enrolment inspired by financial sustainability concerns. In the Faculty of Humanities, at least three departments were closed: "They closed the under-subscribed divisions such as Classics, Afrikaans and Religious Studies". ${ }^{23}$ Besides the perceived low work-utility value, which might have accounted for their demise, department-specific reasons seem to have been behind their closures too. For instance, the programme on Afrikaans could no longer be justified in the light of the new language policy that recognises all other national languages, and thus removed its privileged status as one of two official languages in the country, let alone its negative connotations because of its association with apartheid and its low currency at the international level. While Frank and Gabler's (2006) study uses staff retrenchment and employment trends as an indicator of the flourishing or demise of the disciplines, the staff retrenchment that accompanied this process was very minimal. Therefore it cannot be used as an indicator of changing curriculum at Wits. Here loss of expertise due to staff mobility or re-specialisation has negatively affected curriculum offerings.

Similarly, Religious Studies ${ }^{24}$ faced a number of challenges to survive. The Religious Studies department was one of the biggest departments in the Faculty of Arts until the early 1980s. It "thrived during the 1980s for both political and vocational reasons". ${ }^{25}$ However, this changed drastically from the 1980s to the 1990s as interest in the discipline declined sharply. ${ }^{26}$ This is attributed to a number of factors. First, the programme shifted from Theology to Religious Studies in order to become relevant to a diversity of religions instead of just Christianity. As a result, Religious Studies shifted from a professional focus as a Christian-based vocational preparation to a broader

\footnotetext{
23 Interview, Institutional management, 11 March 2005.

24 It must be noted that information on Religious Studies was based on only one interview since all other staff are no longer at the university.

25 Interview, Social Sciences, 5 December 2007.

26 Interview, Social Sciences, 5 December 2007.
} 
programme with a general focus. ${ }^{27}$ The shift toward increased generality and reduced specificity and professional emphasis collided with the emerging utilitarian discourse. As Frank and Gabler (2006:91) have indicated, Religious Studies were "ceding territory to new age religions" and focusing on wider more inclusive curricula. Second, in the past Religious Studies constituted a highly politicised domain and an important vehicle through which both apartheid and anti-apartheid scholars engaged with the political terrain, though more vulnerable to apartheid manipulation: "[T]he discipline was tainted by the apartheid project." ${ }^{28}$ The role of religion in politics seems to have declined after apartheid. Third, Religious Studies at Wits did not have the advantage of senior and powerful academic authorities who could lobby for its continued existence:

Religious Studies did not have the big names to fight its case of survival in the new efficiency context. For instance, History's survival was partly influenced by the presence of big names like Phil Bonner and Colin Bundy. ${ }^{29}$

Fourth, it has also been suggested that "the Faculty of Arts at Wits was strongly Marxian and did not have much concern about its closure. ${ }^{30}$ In this context, a proposal was put forward to save the discipline by providing service courses to other disciplines and by providing certificate-type programmes on religious issues to the wider public. This was declined and Religious Studies eventually closed down. Finally, Religious Studies also suffered from the fact that some of its more contemporary debates had been incorporated into other disciplinary fields such as History and Political Studies, as the thinning of boundaries between disciplines in the humanities (Bernstein 1971) opened spaces for redefining and reconstituting the disciplines.

With few exceptions the trends in Religious Studies at Wits are echoed in other institutions in South Africa and around the globe. Driven by a strong academic leadership, the programme at the University of Cape Town (UCT) has secured its survival. Some Afrikaans universities re-focused on ethics. The Iranian government supports the University of South Africa (UNISA) in providing a programme in Islamic studies, and the Lutheran Church supports a programme in religious studies at the University of KwaZulu-Natal (UKZN) to meet its professional needs. ${ }^{31}$ Elsewhere in the world Religious Studies or Theology lost more than half of its original space in university education between 1975 and 1995, which has led Frank and Gabler (2006:105) to suggest that society has shifted away from divine capacities and the power of god and religion in shaping their lives and providing the truth.

Nevertheless, despite these closures, some vulnerable disciplines were able to weather the storm. Therefore even though some disciplines were facing closure for not breaking

27 Interview, Social Sciences, 5 December 2007.

28 Interview, Social Sciences, 5 December 2007.

29 Interview, Social Sciences, 5 December 2007.

30 Interview, Social Sciences, 5 December 2007.

31 Interview, Social Sciences, 5 December 2007. 
even, they enjoyed institutional protection in spite of their vulnerability and/or instability. The reasons are again varied, ranging from their perceived national importance or strong academic histories to their political or strategic significance - reasons beyond narrow market-related explanations. Two respondents highlighted this aspect when asked, 'When do you decide to close down disciplines or programmes?':

You have to look at financial viability. And a whole series of questions arise about intellectual viability and contribution. That's a complicated answer which I cannot answer fully now, but finances cannot be the only basis for closing courses. ${ }^{32}$

... It's not just mechanical break-even or you are out. Because we are a university ... ${ }^{33}$

African Languages best represents this case. It has experienced poor student enrolment over the past ten years, given its fragile economic standing compared to English as lingua franca, ${ }^{34}$ which many students associate with success and economic currency (CHE 2010). Some students went to the point of stating that the curriculum of African Languages is neither relevant nor interesting to students. ${ }^{35}$ Despite its difficulties, in 2001, during the restructuring of the faculty, the university agreed that African Languages should be restructured and continue to be offered because of its national importance. ${ }^{36}$ As African languages were marginalised during the apartheid era, the university has put into place a range of policies to validate, protect and promote studies in African languages in line with current national policy.

The protection of African Languages is the result of political imperatives that override efficiency and market pressures. For historical reasons, many students have not yet discovered the value of studying African languages. Within the University, programmes in African Languages are not regarded as cost-effective in terms of staff-to-student ratio, nor as academically sound in their research output. ${ }^{37}$ Despite these reasons, the university decided that they should not be closed down but restructured to attract students, given their national importance. Similarly, History survived the storm despite its low student enrolment, staff retrenchments and the difficulties in breaking even financially. This could also be attributed to the political importance of History and the prestige of the History department as an important critical intellectual space in the South African academic context. Like African languages, History is undergoing

32 Interview, Faculty management, 10 June 2005.

33 Interview, Faculty management, 10 June 2005.

34 In fact, the top-rated universities are all English-medium because research currency is measured through English-language journals. According to the Times Higher QS world ratings, the dominant language of research is English and as a result only one non-Englishspeaking institution qualified for the top 200 university rankings (Harris 2007).

35 Interview, Institutional management, 14 March 2006.

36 Humanities, review (2006:29).

37 Report on the Faculty of Humanities review, 2006. University of the Witwatersrand, S2006/2573. 
an internal restructuring and adaptation to the new academic environment. These examples highlight the fact that it is not possible to assess curriculum change only on the basis of business accounting. This is not to downplay the significance of economic imperatives. Economic responsiveness remains the primary driver of curriculum reform. Within the Wits utilitarian discourse, economic responsiveness is increasingly superseding other forms of usefulness. This means that, though these fields of study have not been closed down, they face severe pressure to swell student numbers and increase their research output at limited costs, all of which have implications for their future sustainability.

\section{MODULARISATION, REPACKAGING AND COURSE PROLIFERATION}

Generally, the literature indicates that the number of degrees, disciplines and courses offered at higher education institutions across the globe has increased substantially and has outstripped programme closures or discontinuations (Becher \& Trowler 2001:14; Kletz \& Pallez 2002:59; Manns \& March 1978:544). Becher and Trowler (2001:14) suggest that the proliferation of disciplines and sub-disciplines should not be underestimated in the macro analysis of higher education curriculum transformation. The Faculty of Humanities at Wits reflects this trend, manifested through more extensive modularisation, programme renewal and course proliferation. Course and programme offerings have increased across the institution; the growth of offerings in the humanities far exceeds that of other faculties. It is estimated that the Faculty of Humanities has approved approximately 150 courses per year (over the past three to four years), which is more than the total number of new courses and programmes developed in all other faculties combined, a trend that outstrips course closures. ${ }^{38}$ These courses are located within as well as outside of traditional disciplines and reflect an attempt to integrate contemporary skills and application-based approaches into the curriculum. For some it was about proliferating "courses that were going to be sexy"39 and attract students.

Underpinning modularisation was a repackaging strategy designed to match the content of the programmes with student interests. Here is an example: Popular in the 1970s and 1980s was radical social history perceived as equipping students with an ideological basis to resist against apartheid (Ludlow 2006:30). When this history lost its significance in this regard, and student enrolments dropped substantially, the History department responded by redesigning its first-year courses to focus on more contemporary issues, perceived as more appealing to students. ${ }^{40}$ It repackaged the first-year curriculum into a course called 'Living with the USA', ${ }^{41}$ which focuses on 'the third world' and the evolution of Africa and India after World War 2, as well as the

38 Informal interview with Kamal Bhagwandas, project coordinator of the Faculty of Humanities Course and Programme Development, Academic Planning Unit, 10 July 2007.

39 Interview, Institutional management, 11 March 2005.

40 Interview, Social Sciences, 8 March 2007.

${ }^{41}$ Social Sciences handbook, Undergraduate studies, 2004. 
so-called 'hotspots' and 'rivals' such as the Middle East and China. In line with Frank and Gabler (2006:178), at Wits, too, the "university History curriculum grew more presentist" over the decade, which also explains why History weathered the storm and only declined slightly when compared to other disciplines in the humanities (Frank \& Gabler 2006:174).

However, while Frank and Gabler (2006) suggest that this trend has led to the decline of the humanities worldwide and the growth of the Social Sciences, as we have argued elsewhere (Cross \& Adam 201 1), the humanities ${ }^{42}$ in South Africa have been the object of internal reconstitution and programme repackaging rather than decline. Neither is the demarcation between the social sciences and the humanities a clear-cut one in the Wits case. The Wits case suggests that disciplines are reconstituting themselves in disciplinary and interdisciplinary ways by focusing on skills and application-based curriculum. However, the nature and extent of this reconstitution varies depending on the different disciplines, their financial and academic stability, and the internal structure of the discipline itself.

\section{REGIONALISATION, INTER-DISCIPLINARITY AND THEMATIC APPROACHES}

'Regionalisation' is the term used by Bernstein (2000) to describe ways in which disciplines coalesce around thematic or topical concerns or come together to focus on fields of practice with a new identity, a key feature of current trends in discipline reconstitution, the emergence of interdisciplinary degree programmes and the development of non-degree programmes designed to suit clients' immediate needs. These changes were driven by student needs, as well as by institutional policy. The process assumed different patterns across departments. The most common pattern took the form of thematically driven modules. Although these modules are theoretically rooted in traditional disciplines, the core organising unit is a theme or concept and not the traditional discipline (e.g. Forced Migration Studies, Journalism, Film and Media Studies). In this perspective, Forced Migration in particular represents the convergence of actors from different disciplines to team-design or team-teach within a fully integrated theme with respect to all aspects of its curriculum design, delivery and organisation. It reflects a total integration approach in which the "linkage idea is central to organising learners' and teachers' working relationships and provides an environment where there is a high level of ideological consensus amongst staff" (Bernstein 1971:64). For Martin and Etzkowitz (2000), these strongly integrated conceptions of interdisciplinarity could be described as 'new disciplines', increasingly recognised as separate entities with their own 'grammar' - rules, methods and focus of study.

The second pattern reflects attempts to recontextualise different aspects of humanities within the framework of a skills discourse or as a strategy for professionalisation of the curriculum in response to market demands. It arises out of programmes or courses that

42 This includes disciplines in the social sciences, as well as humanities. In South Africa the two are usually located in the Faculty of Humanities - the object of the study in this case. 
have been interdisciplinary for a few decades but have become even further removed from the traditional disciplinary bases from which they originally grew, resulting in what could be referred to as a hidden or non-explicit interdisciplinary approach. For instance, Education, originally associated with four key disciplines over the past 10 years Sociology of Education, History of Education, Educational Psychology and Philosophy of Education - is now losing its link with these disciplines at the postgraduate level. This situation is highlighted by the following comment: "So we always were applied because we were always applying from the disciplines. But now the discipline is further and further away from us." ${ }^{43}$

Initial interdisciplinary efforts within this pattern could be referred to as connected but disciplinary, since the disciplines that were taught were discrete but connected through educational issues. However, these traditional disciplines are no longer clearly recognisable ${ }^{44}$ as they are subsumed by organising themes that are strongly located in the context of application - Educational Leadership and Policy Studies, Curriculum Studies, Educational Studies, Democratic Citizenship and Human Rights. History of Education no longer exists, and both Sociology of Education and Philosophy of Education have been integrated into other courses and programmes on an ad hoc basis around social theory issues. It is a case of an integrated approach where the disciplines are present but not explicit; they are now implicit or hidden.

The third pattern comprises thematically based interdisciplinary programmes or courses such as Heritage Studies, taught by different departments or disciplines, in a crossdisciplinary approach that fosters disciplinary collaboration (Lake 1994). The courses and programmes are partially integrated; the lecturers retain disciplinary identities with which they converge and collaborate on joint projects. Very often programmes within this model have one core thematically developed course with other courses drawn from the disciplines involved. The theme or field of practice is the basis for the design of the curriculum, which draws on the theoretical and conceptual lenses of the disciplines. It could be referred to as 'transitory regionalisation', in which regions are formed for the purpose of the course or programme without losing the disciplinary identity.

Briefly, the Wits scenario is varied and complex. Interdisciplinarity remains an experiment in some schools under severe contestation. Interdisciplinarity is spreading with greater speed at the postgraduate level, but it is generally slow in all the schools and departments, which offer non-professional degrees, with some of these showing little or no efforts in this regard (for instance, the School of Human and Community Development or the Department of Philosophy). ${ }^{45}$ Wits responses range from total opposition to interdisciplinarity and strong support for disciplinary learning, pragmatic adoption of interdisciplinarity for responsiveness reasons, support for interdisciplinarity

43 Interview, Education, 7 February 2007.

44 This change has been more drastic for Philosophy and Sociology of Education, while Psychology of Education has remained unchanged in many ways.

45 Faculty review, 2006. Academic Planning Unit. University of Witwatersrand. 
underpinned by a strong disciplinary foundation, to support for interdisciplinarity not overly attached to any form of disciplinary foundation.

\section{GENERICISM: THE RISE OF THE SKILLS DISCOURSE}

The responses to the increasing demand for labour mobility and flexibility as workplace readiness have been associated with the development of generic skills such as communication, presentation and teamwork, also known as soft skills: "If our students are not going to come away being social scientists ... or even necessarily as politically knowledgeable as we'd like them to be, at least they might acquire things like presentation skills or public speaking skills, writing skills". ${ }^{6}$ Soft skills include also what some faculty members described as 'employability skills', which reflect the principles and values from the business world: "Film and Dramatic Arts ${ }^{47}$ [have as their] strategic goal [to achieve] 95\% employability, and they are measured by this ... and they have to teach them employability skills, as well as content. They have to teach them things like entrepreneurship, how to put together a portfolio, etc." ${ }^{48}$ The decision to promote generic skills in the humanities was triggered locally by the findings of a Human Sciences Research Council (HSRC) study that indicated that humanities students took longer to settle into jobs and had lower employment prospects than other students. ${ }^{49}$

Genericism at Wits has been associated with courses that have little or no theoretical content, as well as with courses that are theoretically focused. Furthermore, generic skills may be integrated with content or may be 'content free'. Thus implementation of generic skills could be viewed within a matrix of content-integration strategies versus content-free strategies, as well as explicit theoretical focus and non-explicit theoretical focus. In some cases, the integration of these basic generic skills occurs within existing disciplinary or even interdisciplinary courses and programmes. For instance, Political Science students have to do presentations on key political debates as part of their assessment. In other cases, generic skills are integrated into the formal curriculum through separate modules, directly linked to workplace needs. An interesting example is the module on Music Business Studies, introduced as part of the Music degree programme, which covers topics such as basic financial skills, business management skills, marketing and distribution skills, drawing up contracts and writing funding proposals. ${ }^{50}$ There are also examples where basic skills are introduced independently of the degree programme, through learning units that students can select on an ad hoc and needs basis. These include workshops on topics such as Year Planning and Time Management, Using the Web as a Tool, offered by the Graduate School of Humanities.

\footnotetext{
46 Interview, Social Sciences, 22 January 2007.

47 This refers to the programme of Film and Dramatic Arts in the School of Arts.

48 Interview, Institutional management, 12 May 2005.

49 Graduate School for the Humanities and Social Sciences Review, 2006.

50 Minor academic development, 2004. A2004/267.
} 


\section{'PROFESSIONALISATION' OR VOCATIONALISATION OF HUMANITIES: HIGH SKILLS, LOW THEORY AND STRONG CONTEXTUALISATION}

At the centre of the debates on curriculum reform in the 21 st century is the theory versus skills tension. It is not a new phenomenon. It began as far back as Descartes' analysis of rationalist versus empirical perspectives of knowledge, ${ }^{51}$ Bourdieu's theoretical versus practical logic, Foucault's programmes versus technologies, and Luria's abstract versus situational thinking (Muller 2005:1), and it occupies centre stage in present-day deliberations about university education, which are increasingly geared at addressing the job market:

I would say one of the drivers is this thing about getting a job, career pathing. Many universities are responding by giving students specialist areas for jobs. Parents are also looking for jobs for their children, such as tourism ...52

From a pragmatic utilitarian perspective, Wits reflects a shift in the pendulum from abstract and theoretical curriculum approaches to practical and skills-based approaches as explicitly expressed in its 'Shaping the Future' professionalisation strategy. In some instances this has led to a focus on practice at the expense of theory, strong contextualisation characterised by a low reliance on theory and a high reliance on experience, and concerns with professional rather than the academic dimensions of the curriculum: "I think that one of the major developments that's happened in the humanities in the last few years has been to carry further the relationship between the formative first degree and the professional qualifications ..."53 A recent study conducted by Westerhuizen, Henning, Gherdien and Morris (2007) shows that a range of Master's and $\mathrm{PhD}$ dissertations in educational technology across several institutions were largely practical in nature and did not focus on conceptual or theoretical issues. Within the logic of practice, these dissertations concluded with guidelines and recommendations as opposed to theoretical contributions to the field. Off-loading theory has thus been part of the curriculum renewal strategy in some programmes such as education:

In other words, we didn't read empirical studies; we didn't read specific studies to classrooms, or to curriculum development or to assessment. Nothing like that! It was theorists like Althusser ... So education as a question was more by implication. And the focus was more on the discipline and mainly social theory, as well as - as much as it was developed at the time - educational knowledge, or sociology of knowledge ... Nothing like empirical studies that we are doing today ... ${ }^{54}$

51 Descartes' perspective is that that knowledge is acquired without resort to experience, while empiricists argue that knowledge is derived from experience.

52 Interview, Faculty management, 12 May 2005.

53 Interview, Faculty management, 20 May 2005.

54 Interview, Education, 7 February 2007. 
Where theory still represents a concern, and it is combined with skills development, abstraction tendencies are minimised through strong contextualisation - strong reliance on experience and low reliance on theory:

At the same time we are mindful of the fact that you can't do that in a historical vacuum. So the sort of birth of politics and the context within which theory emerges is a good part of what we deal with ... We still do a more theoretically oriented approach but we try and locate it in what students will be able to hook into that will grab their interest. ${ }^{55}$

While this pressure exists across faculties, Humanities is particularly affected because its curriculum has generally been underpinned by traditional liberal education that has largely been driven by internal developments of the discipline underpinned by a focus on theory. Thus the faculty has been associated with education aimed at cultivating cultural, social and political understandings, and not on serving extrinsic needs (McCabe 2000). However, with university education becoming a passport to getting a job, this approach is under pressure to transform.

\section{COMMODIFICATION AND INCREASING MARKETISATION}

In order to create stronger relationships between academia and the world of work, Wits has introduced a range of programmes and courses that respond to the direct and immediate needs of the workplace. These courses are perceived as being informed by clients' needs but are also driven by income-generation concerns. While short courses have always been part of the institution's offerings, these were very few and located mostly in the Business School. However, the number of short courses increased from 53 between 1993 and 1997 to approximately 124 in the period 1998-2002.56 In terms of the Faculty of Humanities, 66 new short courses were approved between 1993 and 2004. ${ }^{57}$ The bulk of short courses in the faculty are located in the School of the Arts, the School of Language and Literature, and the School of Education. In 2002, Wits set up Wits Enterprise, a separate company, to administer some of these commercial ventures. ${ }^{58}$ Since 2007, the School of Languages has offered a range of courses in European, Asian and African languages, as well as courses in Business English and Spoken Business English. The School of the Arts offers a range of courses such as Image Manipulation, Digital Video, Final Cut Editing and Macro Media Flash. ${ }^{59}$ In addition to courses run by Wits Enterprise, some courses are run directly through the schools. Examples include Democracy Training for Professionals in Political Studies, Quality Assurance through Whole School Evaluation in Education,

55 Interview, Social Sciences, 7 February 2007.

56 Policy on short courses, version 2, undated.

57 Database of ABEX-approved short courses on offer at Wits for the period 1993-2004. A2004/711. 2004.

58 HEQC self-evaluation report. University of the Witwatersrand, 2006.

59 Short course directory, Wits Enterprise, 2007, University of the Witwatersrand. 
Translation and Interpretation courses in the School of Language and Literature, and courses on Newspaper and Magazine Design and Television Studies in the School of the Arts.

This is a case of extreme disciplinary regionalisation and reconstitution driven by the external environment with little focus on the inner disciplinary principles as the organising concept of the curriculum. This form of regionalisation or disciplinary reconstitution is skewed heavily away from the 'sacred' or from systematic theoretical learning (Beck 2002:619). Thus the link between the new courses and programmes and the initial discipline is substantially reduced or limited, with implications for knowledge conception and academic identity.

\section{WHAT DOES IT ALL MEAN?}

Our brief reflection on the most recent events in the curriculum process of the Faculty of Humanities points to very interesting theoretical insights, some of them suggestive of the main trends in the reconceptualisation of higher education content in South Africa. First it appears that generally the balance sheet is not as gloomy as some analysts such as Muller (2005) and Jansen (2004) have painted it, at least in terms of the volume and scale of the Humanities project. In other words, what we are noticing is not an apocalyptical finale or a 'decline' as the humanities have repeatedly been described. What we are seeing is a ferocious, nervous and somewhat absurd re-recomposition of the Humanities project. Two aspects are worth highlighting in this regard.

On the positive side, the process is strategic in that it challenges the humanities to recreate the conditions of possibility for its existence in the future. International debates call for the reconstituting of the humanities. This is eloquently dramatised by Donoghue (2008) in The Last Professor and well illustrated by the Wits remodelling of its Humanities programmes, which suggests that the Humanities project may have to abandon its traditional rationales for its existence i.e. those associated with the Oakeshottian concept of learning just for the sake of understanding and explaining or keeping its distance from intervening in the social, economic and political turmoil of the contemporary world. Particularly in the developing world, current national and international agendas set at least three key priorities for higher education and the Humanities project in particular: (1) to inform transformation and development; (2) to help deal; to rebuild a sense of nationhood and independence reconcilable with national and international interdependence and harmony; and (3) to enable individuals and society at large to participate in the community of nations. In this regard, several curriculum initiatives have revealed that beyond 'understanding' and 'explaining', some discipline-rooted knowledge practices can directly inform practice and interventions in several domains of life. In performing these tasks, the Humanities project should not negate but reinforce its basis in the learning-understandingand-explaining connection, as well as its role in the development of critical, socially embedded and autonomous citizens. 
On the downside, there is definitely a danger of annihilating some of the most powerful attributes associated with the liberal arts tradition if the utilitarian discourse is taken to its extreme form. Thus there is a danger of confusing recomposition or reconstitution or even more appropriately adaptation in the humanities with decomposition of the Humanities project. Training for jobs and producing technicians do not fit well with the Humanities project and should not be foregrounded in knowledge and curriculum decision making for programmes in the humanities. In this regard, we would like to draw attention to Alvin Toffler's (2008:4) famous prophecy: "The illiterate of the 21 st century will not be those who cannot read and write, but those who cannot learn, unlearn and relearn". ${ }^{60}$ The Humanities project has a role in preventing such a catastrophe and should not succumb to market-driven imperatives that will destroy its invaluable contribution to the development of citizens who are able to think critically, who are grounded in conceptual and theoretical knowledge, who are able to respect and understand different perspectives and who can contribute to a democratic society. These are not unaffordable luxuries but essential ingredients for the flourishing of stable and democratic societies. Clearly there is a need for arriving at a strategic compromise between the extreme market-driven curricula and the extreme, traditional liberal curricula that contribute to societies but adhere to some of the critical approaches offered by the humanities.

Finally, epistemologically and methodologically, the chapter has serious implications. Uncritical totalising discourses are more likely to conceal than to reveal contextual complexities in curriculum reform. Today there are overriding global forces that must be acknowledged. While these are important factors in curriculum reform, they must be examined in historical terms, particularly in the context of higher education in developing countries such as South Africa. This chapter points to the need for systematic scrutiny of the variables that influence curriculum development in different national and cultural settings and acknowledges that drivers and mediators of the process vary in different contexts. Curriculum transformation in higher education is a complex process of negotiation that takes account of the interests and power relations of different players, the knowledge and identity associated with particular disciplines or programmes and the specific social, political and economic contexts of the society:

Thus sweeping generalisations do not sufficiently and accurately account for the complexity of responses and outcomes at the institutional or faculty level. Curriculum reform therefore results from the interplay of a number of external and internal factors that occur within very specific contextual conditions (Adam 2009:ii).

60 Higher Education in Developing Countries, WB Report. 
PART ONE • REVITALISING CURRICULUM INQUIRY - PERSPECTIVES OF RESEARCHERS

\section{REFERENCES}

Adam F. 2009. Curriculum reform in higher education: a humanities case study. University of the Witwatersrand: Unpublished PhD thesis.

Becher T \& Trowler P. 2001 . Academic tribes and territories: Intellectual enquiry and the cultures of disciplines. Buckingham: Society for Research into Higher Education \& Open University Press.

Beck J. 2002. The sacred and the profane in recent struggles to promote official pedagogic identities. British Journal of the Sociology of Education, 23(4):617-626.

Beck J \& Young M. 2005. The word and the world: the assault on the professions and the restructuring of academic and professional identities - a Bernsteinian analysis. British Journal of the Sociology of Education, 26(2):183-197.

Bernstein B. 1971. On the classification and framing of knowledge. In: M Young (ed). Knowledge and control: New directions for the sociology of education. London: Collier Macmillan. 47-69.

Bernstein B. 2000. Pedagogy, symbolic control and identity: Theory, research, critique. Revised Edition. London: Taylor \& Francis.

Castells M. 2001. Information technology and global development. In: J Muller, N Cloete \& S Badat (eds). Challenges of globalisation: South African debates with Manuel Castells. Cape Town: Maskew Miller Longman. 152-167.

CHE (Council on Higher Education). 2010. Access and throughput in South African higher education: Three case studies. Monitor, 9. March.

Cross M \& Adam F. 2011 . Liberal learning, social responsibility and higher education curriculum in South Africa. Draft chapter submitted for publication to the Institute for Higher Education Policy, Washington, DC.

Donoghue F. 2008. The last professors: The corporate university and the fate of the humanities. New York: Fordham University Press.

Dovlo E. 2007. The 'relevant' university: The Ghanaian experience. Social Dynamics, 33(1):212-216.

Duncan G. 2008. Counting the currency of knowledge. New Zealand's Performance-Based Research Fund. In: I Morely \& M Crouch (eds). Knowledge as value: Illumination through critical prisms. Amsterdam: Rodopi PV. 23-42. [Retrieved January 2009] www.interdisciplinary.net/ati/education/tvk/.../Duncan\%20paper.pdf

Enslin P. 2003. Citizenship education in post-apartheid South Africa. Cambridge Journal of Education, 33(1):73-83.

Ensor P. 2002. Curriculum. In: N Cloete, R Fehnel, P Maassen, T Moja, H Perold \& T Gibbon (eds). Transformation in higher education: Global pressures and local realities in South Africa. Lansdowne: Juta. 270-295.

Fish S. 2009. The last professor. New York Times. 18 January 2009. [Retrieved November 2010] http://opinionator.blogs.nytimes.com/2009/01/18/the-last-professor/

Frank D \& Gabler J. 2006. Reconstructing the university: Worldwide shifts in academia in the 20th century. Stanford, CA: Stanford University Press. 
Gibbons M. 2000. Universities and the new production of knowledge: some policy implications for government. In: A Kraak (ed). Changing modes: new knowledge production and its implications for higher education. Pretoria: Human Sciences Research Council.

Gibbons M, Limoges C, Nowotny H, Schwartzman S, Scott P \& Trow M. 1994. The new production of knowledge: The dynamics of science and research in contemporary societies. London: Sage.

Hanson V, Heath J \& Thornton B. 2001. Bonfire of the humanities: Rescuing the classics in an impoverished age. Boston, MA: Harvard University Press.

Jansen JD. 2004. Changes and continuities in South Africa's higher education system, 1994 to 2004. In: L Chisholm (ed). Changing class. Pretoria: Human Sciences Research Council. 293-324.

Kletz F \& Pallez F. 2002. Taking decisions on new curricula in French universities: Do disciplinary criteria still prevail? European Journal of Education, 37(1):57-70.

Kraak A. 1997. Globalisation, changes in knowledge production, and the transformation of higher education. In: N Cloete, J Muller, M Makgoba \& D Ekong (eds). Knowledge identity and curriculum transformation in Africa. Cape Town: Maskew Miller Longman.

Kraak A. 2000. Changing modes: A brief overview of the mode 2 knowledge debate and its impact on South African policy formulation. In: A Kraak (ed). Changing modes: New knowledge production and its implications for higher education. Pretoria: Human Sciences Research Council. 1-37.

Lake K. 1994. Integrated curriculum in education. In: Department of Education (ed). School improvement research series. Canberra: Office of Educational Research and Improvement, University of Canberra. 1-14.

Ludlow EH. 2006. Apprenticing undergraduate History students into interpretive practice through local history. Master's thesis. Johannesburg: University of the Witwatersrand.

Manns CL \& March JG. 1978. Financial adversity, internal competition and curriculum change in a university. Administrative Science Quarterly, 23(4):54 1-552.

Martin BR \& Etzkowitz H. 2000. The origin and evolution of the university species. Journal of Science and Technology Studies, 13:9-34.

McCabe D. 2000. Michael Oakshott and the idea of liberal education. Social Theory and Practice, 26(33):443-464. [Retrieved March 2009] http://public.clunet.edu

Muller J. 2000. What knowledge is of most worth for the millennial citizen? In: A Kraak (ed). Changing modes: New knowledge production and its implications for higher education. Pretoria: Human Sciences Research Council. 70-87.

Muller J. 2003. Knowledge and the limits of institutional restructuring: The case of South African higher education. Journal of Education, 30:101-126.

Muller J. 2005. The world is not enough: Knowledge in question. South African Journal of Higher Education, 19(3):497-511.

Perloff M. 2001. Crisis in the humanities. [Retrieved March 2009] http://epc.buffalo.edu/ authors/prloff/articles/crisis.html

Ramirez FO. 2004. The rationalization of universities. In: M Dielic \& K Shalin-Andersson (eds). Transnational regulation. Cambridge: Cambridge University Press. 224-245. 
PART ONE • REVITALISING CURRICULUM INQUIRY - PERSPECTIVES OF RESEARCHERS

Readings B. 1996. The university in ruins. Cambridge, MA: Harvard University Press.

Sanderson M. 1993. Vocational and liberal education: A historian's view. European Journal of Education, 28(2):189-196.

Scott P. 1997. Changes in knowledge production and dissemination in the context of globalization. In: N Cloete, J Muller, MW Makgoba \& D Ekong (eds). Knowledge identity and curriculum transformation in Africa. Cape Town: Maskew Miller Longman. 17-42.

Searle J. 1990. The storm over the university. New York Review of Books. [Retrieved May 2010] http://www.ditext.com/searle/searle 1.html

Tapp R. 1997. The demise of the humanities department at the University of Minnesota. North American Community for Humanism. [Retrieved November 2008] http://www.humanism. org/vol 11

Toffler A. 2008. Learning for the 21 st century: A report and mile guide for 21 st century skills. Partnership for 21 st century skills. AOL Time Warner Foundation.

Tsui L. 2002. Fostering critical thinking through effective pedagogy: Evidence from four institutional case studies. Journal of Higher Education, 73:740-763.

Westerhuizen DVD, Henning E, Gherdien NA \& Morris J. 2007. The scholarship of educational ICT postgraduate studies in South Africa. Johannesburg: University of Johannesburg. 